ATTHULAB:

Islamic Religion Teaching \& Learning Journal

Volume 5 Nomor 1 Tahun 2020

http://journal.uinsgd.ac.id./index.php/atthulab/

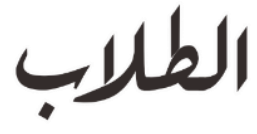

\title{
Integrasi Pembelajaran Kitab Kuning dalam Pembelajaran PAI
}

\author{
Ali Murtado ${ }^{1)}$ dan Mohamad Erihadiana2) \\ 1) Pascasarjana UIN Sunan Gunung Djati Bandung \\ Email: alimurtadosubang@gmail.com \\ 2) Universitas Islam Negeri Sunan Gunung Djati Bandung \\ J1. Soekarno Hatta Cimincarang Kec. Gedebage Kota Bandung, Jawa Barat, Indonesia \\ Email: erihadiana@uinsgd.ac.id
}

\begin{abstract}
This study aims to determine the curriculum structure of the PAI subjects at MTs Plus Karangwangi Subang. The type of research used is qualitative research. While the techniques in data collection are through interviews, observations, and documentation. The results of this study are in the MTs Plus Karangwangi curriculum adding hours and PAI subject matter from the number of hours and materials set by the government in the 2013 curriculum, as an effort to mature students in understanding the teachings of Islam.
\end{abstract}

Keywords: Curriculum; Yellow Book; PAI.

Abstrak: Penelitian ini bertujuan untuk mengetahui struktur kurikulum mata pelajaran PAI di MTs Plus Karangwangi Subang. Jenis penelitian yang digunakan adalah penelitian kualitatif. Sedangkan teknik dalam pengumpulan data yaitu melalui wawancara, observasi (pengamatan), dan dokumentasi. Hasil penelitian ini yaitu dalam kurikulum MTs Plus Karangwangi menambahkan jam dan materi pelajaran PAI dari jumlah jam dan materi yang sudah ditetapkan oleh pemerintah dalam kurikulum 2013, hal ini sebagai upaya dalam rangka mematangkan siswa dalam memahami ajaran Agama Islam.

Kata Kunci: Kurikulum; Kitab Kuning; PAI.

DOI: http://dx.doi.org/10.15575/ath.v5i1.7370

Received: 03, 2020. Accepted: 04, 2020. Published: 04,2020.

\section{PENDAHULUAN}

Secara etimologis Kurikulum (Curriculum) berasal dari bahasa Yunani curir yang artinya "pelari" dan curere yang berarti "tempat berpacu" atau "jarak yang ditempuh". Istilah ini semula dipakai dalam dunia olahraga. Jadi, istilah kurikulum berasal dari dunia olahraga pada zaman Romawi Kuno di Yunani yang mengandung pengertian satu jarak yang harus ditempuh oleh pelari dari garis start sampai garis finis (At-Taubany \& Susena, 2017). Dalam proses lebih lanjut istilah ini ternyata mengalami perkembangan sehingga penggunaan istilah ini meluas dan merambah ke dunia pendidikan, sejauh ini belum diketahui secara pasti kapan istilah kurikulum masuk ke dunia pendidikan (Sarinah, 2015). Di Indonesia sendiri, pengertian kurikulum terdapat dalam pasal 1 butir 19 UU Nomor 20 Tahun 2003 tentang Sistem Pendidikan Nasional yaitu Kurikulum adalah seperangkat rencana dan pengaturan mengenai tujuan, isi, dan bahan pelajaran serta cara yang digunakan sebagai pedoman penyelenggaraan kegiatan pembelajaran untuk mencapai tujuan pendidikan tertentu. (UndangUndang Republik Indonesia Nomor 20 Tahun 2003 Tentang Sistem Pendidikan Nasional, n.d.). 
Untuk lebih memahami pengertian kurikulum, marilah kita simak beberapa definisi kurikulum menurut para ahli di bawah ini:

1. Menurut Daniel Tanner dan Laurel Tanner, kurikulum adalah pengalaman pembelajaran yang terarah dan terencana secara restruktur dan tersusun melalui proses rekonstruksi pengetahuan dan pengalaman secara sistematis yang berada di bawah pengawasan lembaga pendidikan sehingga pelajar memiliki motivasi dan minat belajar.

2. Menurut Inlow (1966), kurikulum adalah usaha menyeluruh dirancang khusus oleh sekolah dalam membimbing murid memperoleh hasil dari pelajaran yang telah ditentukan.

3. Hilda Taba (1962), kurikulum sebagai Plan of learning yang berarti bahwa kurikulum adalah satu yang direncanakan untuk dipelajari oleh siswa yang memuat rencana untuk peserta didik.

4. Kerr, J. F (1968), kurikulum adalah sebuah pembelajaran yang dirancang dan dilaksanakan dengan individu dan berkelompok baik di luar maupun di dalam sekolah.

5. George A. Beaucham (1976), kurikulum adalah dokumen tertulis yang mengandung isi mata pelajaran yang diajar kepada peserta didik melalui berbagai mata pelajaran, pilihan disiplin ilmu, rumusan masalah dalam kehidupan sehari-hari.

6. Neagley dan Evans (1967), kurikulum adalah semua pengalaman yang telah dirancang oleh pihak sekolah untuk menolong para siswa dalam mencapai hasil belajar kepada kemampuan siswa yang paling baik.

7. UU. No. 20 Tahun 2003, kurikulum adalah seperangkat rencana dan pengaturan mengenai tujuan, isi, dan bahan pengajaran serta cara yang digunakan sebagai pedoman penyelenggaraan kegiatan pembelajaran untuk mencapai tujuan pendidikan nasional.

8. Crow Ana Crow, kurikulum adalah rancangan pengajaran atau sejumlah mata pelajaran yang disusun secara sistematis untuk menyelesaikan satu program untuk memperoleh ijazah (Sarinah, 2015).

Kurikulum mempunyai kedudukan sentral dan peranan yang sangat penting dalam seluruh proses pendidikan. Kurikulum bertujuan sebagai arah, pedoman, atau sebagai rambu-rambu dalam pelaksanaan proses pembelajaran. Kurikulum mengarahkan segala bentuk aktivitas pendidikan demi tercapainya tujuan pendidikan. Dengan kata lain bahwa kurikulum sebagai alat untuk mencapai tujuan pendidikan yaitu pembentukan manusia yang sesuai dengan falsafah hidup bangsa memegang peranan penting dalam suatu sistem pendidikan (Lismina, 2017). Maka kurikulum sebagai alat untuk mencapai tujuan harus mampu mengantarkan anak didik menjadi manusia yang beriman dan bertaqwa, berakhlak mulia, cerdas, terampil dan berbudi luhur, berilmu, tidak hanya sebagai mata pelajaran yang harus diberikan kepada peserta didik semata, melainkan sebagai aktivitas pendidikan yang direncanakan untuk dialami, diterima, dan dilakukan.

Secara garis besar, saat ini di Indonesia terdapat dua jenis lembaga pendidikan formal, yaitu 1) lembaga pendidikan umum dan lembaga 
pendidikan yang bercirikhaskan Islam, untuk pendidikan umum berada di bawah naungan Kementrian Pendidikan Dan Kebudayaan (Kemendikbud) dan lembaga pendidikan tersebut disebut dengan istilah Sekolah dan 2) lembaga pendidikan yang bercirikhaskan Islam berada di bawah naungan Kementrian Agama yang kemudian disebut dengan istilah Madrasah.

Dalam sejarah pendidikan di Indonesia sudah beberapa kali diadakan perubahan dan perbaikan kurikulum yang tujuannya sudah tentu untuk menyesuaikan dengan perkembangan dan kemajuan zaman, guna mencapai hasil yang maksimal. Pada tahun 2013 Menteri Pendidikan Indonesia, Mohammad Nuh, telah menetapkan kurikulum baru bagi pendidikan di Indonesia yakni Kurikulum 2013. Kurikulum 2013 merupakan penyempurnaan dari kurikulum sebelumnya yaitu Kurikulum Tingkat Satuan Pendidikan atau yang disebut kurikulum 2006. Kurikulum 2013 disusun berdasar pada budaya dan karakter bangsa Indonesia, berbasis peradaban dan berbasis kompetensi. Kurikulum ini juga dikembangkan secara integratif, dinamis, komprehensif, akomodatif dan aspiratif terhadap tantangan masa depan. Penekanan pada penyempurnaan pola pikir, pendalaman dan perluasan materi, penguatan proses pembelajaran dan penyesuaian beban belajar agar dapat menjamin kesesuaian yang diinginkan dengan yang dihasilkan (Shobirin, 2016).

Selanjutnya, pada tahun 2014 Kementrian Agama Republik Indonesia mengeluarkan keputusan Nomor 117 tentang Implementasi Kurikulum 2013 di Madrasah yang mana isinya menetapkan bahwa Implementasi Kurikulum 2013 di Madrasah harus diberlakukan dan dilaksanakan mulai tahun pelajaran 2014/2015. Pada tahun pelajaran 2014/2015 tersebutlah madrasah memulai menggunakan kurikulum 2013. Dalam kurikulum baru 2013 yang dikeluarkan oleh Kemendikbud, Pendidikan Agama Islam di sekolah dasar dan sekolah menengah digabung dengan Pendidikan Budi Pekerti, sehingga namanya menjadi Pendidikan Agama Islam dan Budi Pekerti. Pendidikan Agama Islam diajarkan selama 4 jam pelajaran per minggu di jenjang sekolah dasar dan 3 jam pelajaran per minggu di jenjang sekolah menengah. Sedangkan dalam kurikulum 2013 yang dikeluarkan oleh Kementrian Agama, mata pelajaran PAI sebanyak 8 jam pelajaran yang terbagi ke dalam 4 rumpun mata pelajaran PAI yaitu mata pelajaran Al-Quran hadis, Akidah Akhlak, Fikih dan SKI. Sehingga jelas ada perbedaan jumlah jam pelajaran PAI di sekolah dan di madrasah.

Dalam kurikulum 2013 yang dikeluarkan kementrian Agama, jumlah jam pelajaran PAI lebih banyak jika dibandingkan dengan kurikulum 2013 kemendikbud, namun dalam keadaan di lapangan masih banyak masyarakat dan tokoh agama di Indonesia masih saja kurang puas dengan jumlah jam pelajaran agama dalam kurikulum yang sudah diatur oleh pemerintah tersebut. Sebagai cara menutupi kekecewaan atau ketidakpuasan mengenai jumlah jam pelajaran PAI tersebut, banyak organisasi-organisasi Islam atau yayasan pendidikan Islam mencoba mengatasinya dengan membentuk sekolah-sekolah atau madrasah-madrasah unggulan di semua tingkatan pendidikan, bahkan sejak PAUD, yang pada dasarnya ingin tetap mengajarkan ilmu-ilmu agama atau mengintensifkan pelajaran PAI serta kegiatan keagamaan dengan cara yang 
beragam, seperti menambah jam pelajaran PAI atau memasukan pelajaran kitab kuning dalam kurikulum pendidikan agama Islam.

Berdasarkan penelitian bahwa pendidikan agama yang diterapkan di sekolah/madrasah memiliki pengaruh yang signifikan terhadap perilaku keagamaan peserta didik, oleh karena itu bisa dikatakan bahwa semakin banyak jam pelajaran PAI maka perilaku keagamaannya akan semakin baik (Mukhtaruddin, 2011). Oleh karena itu, menjadi penting menambah jam pelajaran PAI di sekolah-sekolah/madrasah-madrasah demi terciptanya perilaku peserta didik yang sesuai dengan ajaran agama Islam, dan mengenai kekurangan jam pelajaran PAI di sekolah-sekolah umum juga merupakan hal yang sangat sering dikemukakan oleh para pengamat pendidikan Islam. Karena masalah inilah yang dianggap sebagai penyebab utama timbulnya kekurangan para pelajar dalam memahami, menghayati, dan mengamalkan ajaran agama. Sebagai akibat dari kekurangan ini, para pelajar tidak memiliki bekal yang memadai untuk membentengi dirinya dari berbagai pengaruh negatif akibat globalisasi yang menerpa kehidupan. Banyak pelajar yang terlibat dalam perbuatan yang kurang terpuji seperti tawuran, pencurian, penodongan, penyalahgunaan obat narkotik dan sebagainya. Hal ini disebabkan salah satunya karena kekurangan bekal pendidikan agama (Nata, 2012).

Pendidikan Agama Islam adalah upaya sadar dan terencana dalam menyiapkan peserta didik untuk mengenal, memahami, menghayati, hingga mengimani, bertakwa dan berakhlak mulia dalam mengamalkan ajaran agama Islam dari sumber utamanya kitab suci Al-Qur'an dan Hadis melalui kegiatan bimbingan, pengajaran, latihan serta penggunaan pengalaman (Dahwadin \& Nugraha, 2019). Pendidikan Agama Islam adalah pendidikan yang kompleks dan komprehensif menyentuh seluruh ranah pendidikan, baik ranah kognitif, afektif maupun psikomotorik. Pendidikan Agama Islam selain menyampaikan materi pengetahuan agama kepada siswa juga membimbing siswa untuk bersikap atau berperilaku sesuai dengan nilai-nilai yang diajarkan agama yang mengedepankan akhlakul karimah sebagai perilaku dasar yang harus dimiliki oleh semua siswa (Syarif, 2017).

Jika kita cermati, bahwa dalam tujuan Pendidikan Agama Islam (PAI) ada beberapa aspek yang hendak ditingkatkan dan dituju oleh kegiatan Pendidikan Agama Islam yaitu aspek kognitif, afektif dan psikomotor. Dalam aspek kognitif, siswa diharapkan mampu memahami Islam dengan paradigma yang benar (berfikir paradigmatis). Kemudian dalam aspek afektif, agar anak didik mampu mengapresiasi Islam secara mendalam sehingga mereka mampu mengimani kebenaran Islam, mampu mengelola emosinya secara benar, dan mampu menghayati ajaran Islam sehingga dapat meningkatkan keimanan dan ketakwaan. Sedangkan dalam aspek psikomotor, siswa diharapkan mampu mengamalkan ajaran Islam secara komprehensif, baik dalam hablum minallah (hubungan vertikal), hablun minannas, dan hablun minal'alam (hubungan horizontal)(Kosim \& Faturrohman, 2018). Pendidikan agama Islam yang diberikan kepada peserta didik juga dimaksudkan agar peserta didik memiliki kepribadian yang tidak mudah dipengaruhi oleh dampak negatif yang terjadi di 
lingkup kehidupan sosial yang lebih luas (H. Tahang, 2010). Sementara itu, untuk tujuan akhir dari pendidikan agama Islam adalah terwujudnya insan yang berperilaku al-Qur'an, atau manusia yang sanggup dan mampu melaksanakan seluruh ajaran yang terdapat di dalam al-Qur'an tanpa kecuali, secara integral dan komprehensif, baik itu dalam kehidupan pribadi maupun dalam masyarakat (Kosim \& Faturrohman, 2018).

Untuk mencapai tujuan pendidikan agama Islam tersebut di atas maka perlu adanya integrasi pembelajaran kitab kuning dalam pembelajaran PAI di sekolah maupun di madrasah, karena dapat diperhatikan secara akurat bahwa ajaran-ajaran dalam Islam ditulis dalam kitab kuning. Jika dilihat pada zaman dahulu kitab kuning dikembangkan melalui halaqoh, pembelajarannya tidak terprogam dengan baik. Pada saat ini kitab kuning dikembangkan melalui pendidikan formal, sekolah/madrasah maupun pesantren (Syaifullah, 2017). Penelitian ini menjelaskan struktur kurikulum mata pelajaran PAI di MTs Plus Karangwangi Subang dan membandingkannya dengan struktur kurikulum yang dikeluarkan oleh pemerintah baik itu struktur kurikulum yang dikeluarkan oleh kementrian agama maupun oleh kementrian pendidikan dan kebudayaan. Sehingga dapat terlihat betapa pentingnya menambah jumlah jam pelajaran PAI di sekolah maupun di madrasah sebagai upaya dalam rangka mematangkan siswa dalam memahami ajaran Agama Islam dan demi tercapainya tujuan pendidikan agama Islam, dan ini merupakan sebagai bukti bahwa terdapatnya tokoh masyarakat yang kurang puas terhadap aturan pemerintah yang berkaitan dengan jumlah jam pelajaran PAI di sekolah yang berlaku saat ini dan mereka menginginkan adanya integrasi pembelajaran kitab kuning dalam pembelajaran PAI di sekolah maupun di madrasah.

Penelitian ini berbeda dengan penelitian sebelumnya yang telah dilakukan oleh Munir dalam jurnalnya yang berjudul "Pengembangan Materi Pendidikan Agama Islam (PAI) berbasis Kitab Kuning dan Signifikansinya dengan Karakter Siswa SMA Ahmad Yani 2 Baureno Bojonegoro" jurnal Keagamaan dan Pembelajarannya, Universitas Islam Darul 'Ulum Lamongan, 2018. Dalam penelitian yang dilakukannya yaitu mendeskripsikan pengembangan materi pendidikan agama Islam yang berbasis kitab kuning dan signifikansinya pelaksanaan pendidikan agama Islam berbasis kitab kuning terhadap karakter siswa. Dalam penelitian yang dilakukan Munir menghasilkan bahwa pengembangan kurikulum PAI berbasis kitab kuning sangat berpengaruh baik dalam karakter siswa yang meliputi ketaatan, kedisiplinan, sopan santun pada guru, teman maupun orang tua (Munir, 2018).

\section{METODE PENELITIAN}

\section{Pendekatan dan Metode Penelitian}

Dalam penelitian ini penulis menggunakan pendekatan kualitatif. Artinya data yang dikumpulkan bukan berupa angka-angka, melainkan data yang berasal dari hasil wawancara, observasi dokumen pribadi, catatan, memo dan dokumen resmi lainnya. sehingga yang menjadi tujuan dari penelitian kualitatif adalah menggambarkan realita empirik dibalik fenomena secara mendalam, 
rinci dan tuntas (Moleong, 2003). Adapun metode yang digunakan dalam penelitian ini adalah metode kualitatif yang berlangsung dalam latar belakang yang wajar dengan menggunakan fenomenologis, karena itu data yang dikumpulkan lebih banyak merupakan data-data kualitatif yaitu penelitian yang bermaksud untuk memahami fenomena tentang apa yang dialami oleh subyek penelitian misalnya perilaku, persepsi, motivasi, tindakan dan lain-lain (Moleong, 2008).

2. Jenis dan Sumber Data

1) Jenis Data

Jenis data yang digunakan yaitu data kualitatif. Data Kualitatif adalah data yang dinyatakan dalam bentuk kata, kalimat dan gambar. Data kualitatif dapat diperoleh melalui wawancara, observasi, diskusi atau pengamatan.

2) Sumber data

Sumber data dalam penelitian ini dibagi menjadi dua jenis data, yaitu sumber data primer dan sumber data sekunder. Sumber data primer, yaitu data-data yang diambil secara langsung oleh peneliti dari sumbernya, seperti melalui observasi, wawancara, dan dokumentasi di tempat penelitian. Sedangkan sumber data sekunder adalah data-data lain yang sudah tersedia seperti profil sekolah, Dokumen Kurikulum, RPP, arsip pembelajaran PAI.

3. Metode Penelitian dan Teknik Pengumpulan Data

Teknik pengumpulan data merupakan langkah yang paling utama dalam penelitian, karena tujuan utama dari penelitian adalah mendapatkan data. Data yang diperlukan dalam penelitian ini adalah data primer dan data sekunder, data primer (pokok) diambil melalui pengamatan dan wawancara, sedangkan data sekunder (pendukung) diperoleh melalui dokumentasi (Sugiyono, 2009).

4. Waktu dan Tempat Penelitian

Penelitian dilaksanakan pada tanggal 23 s.d. 30 September 2019. Adapun tempat penelitiannya ialah di MTs Plus Karangwangi Subang.

\section{HASIL PENELITIAN DAN PEMBAHASAN}

1. Kurikulum 2013 Mata Pelajaran PAI berdasarkan KMA RI Nomor 165 Tahun 2014 di Madrasah

Kerangka dasar kurikulum Madrasah merupakan landasan filosofis, sosiologis, psikopedagogis dan yuridis yang berfungsi sebagai acuan pengembangan struktur kurikulum. Sedang struktur kurikulum Madrasah merupakan pengorganisasian kompetensi inti, mata pelajaran, beban belajar dan kompetensi dasar pada setiap Madrasah.

Kompetensi Inti (KI) kurikulum adalah pengikat berbagai kompetensi dasar yang harus dihasilkan dengan mempelajari tiap mata pelajaran serta berfungsi sebagai integrator horisontal antar mata pelajaran. Rumusan Kompetensi Inti menggunakan notasi: 1) KI-1 untuk Kompetensi Inti sikap spiritual, 2) KI-2 untuk Kompetensi Inti sikap sosial, 3) KI-3 untuk Kompetensi 
Inti pengetahuan (pemahaman konsep), 4) KI-4 untuk kompetensi inti keterampilan.

Kompetensi Dasar adalah kompetensi setiap mata pelajaran untuk setiap kelas yang diturunkan dari Kompetensi Inti. Kompetensi Dasar merupakan konten atau kompetensi yang terdiri atas sikap, pengetahuan, dan keterampilan yang bersumber pada kompetensi inti yang harus dikuasai peserta didik. Kompetensi tersebut dikembangkan dengan memperhatikan karakteristik peserta didik, kemampuan awal, serta ciri dari suatu mata pelajaran, mengingat standar kompetensi lulusan harus dicapai pada akhir jenjang.

Tabel 1.

Kompetensi Inti Madrasah Tsanawiyah (MTs)

\begin{tabular}{|c|c|c|}
\hline $\begin{array}{c}\text { KOMPETENSI INTI } \\
\text { KELAS VII } \\
\end{array}$ & $\begin{array}{c}\text { KOMPETENSI INTI } \\
\text { KELAS VIII } \\
\end{array}$ & $\begin{array}{c}\text { KOMPETENSI INTI } \\
\text { KELAS IX } \\
\end{array}$ \\
\hline $\begin{array}{l}\text { 1. Menghargai dan } \\
\text { menghayati } \\
\text { ajaran agama yang } \\
\text { dianutnya. }\end{array}$ & $\begin{array}{l}\text { 1. Menghargai dan } \\
\text { menghayati } \\
\text { ajaran agama yang } \\
\text { dianutnya. }\end{array}$ & $\begin{array}{l}\text { 1. Menghargai dan } \\
\text { menghayati ajaran } \\
\text { agama yang dianutnya. }\end{array}$ \\
\hline $\begin{array}{l}\text { 2. Menghargai dan } \\
\text { menghayati } \\
\text { perilaku jujur, disiplin, } \\
\text { tanggung jawab, peduli } \\
\text { (toleransi, gotong } \\
\text { royong), } \\
\text { santun, percaya diri, } \\
\text { dalam } \\
\text { berinteraksi secara } \\
\text { efektif } \\
\text { dengan lingkungan } \\
\text { sosial } \\
\text { dan alam dalam } \\
\text { jangkauan } \\
\text { pergaulan dan } \\
\text { keberadaannya }\end{array}$ & $\begin{array}{l}\text { 2. Menghargai dan } \\
\text { menghayati } \\
\text { perilaku jujur, disiplin, } \\
\text { tanggung jawab, peduli } \\
\text { (toleransi, gotong } \\
\text { royong), } \\
\text { santun, percaya diri, } \\
\text { dalam } \\
\text { berinteraksi secara } \\
\text { efektif } \\
\text { dengan lingkungan } \\
\text { sosial } \\
\text { dan alam dalam } \\
\text { jangkauan } \\
\text { pergaulan dan } \\
\text { keberadaannya }\end{array}$ & $\begin{array}{l}\text { Menghargai dan } \\
\text { menghayati } \\
\text { perilaku jujur, disiplin, } \\
\text { tanggung jawab, peduli } \\
\text { (toleransi, gotong } \\
\text { royong), } \\
\text { santun, percaya diri, } \\
\text { dalam } \\
\text { berinteraksi secara } \\
\text { efektif } \\
\text { dengan lingkungan } \\
\text { sosial dan alam dalam } \\
\text { jangkauan } \\
\text { pergaulan dan } \\
\text { keberadaannya }\end{array}$ \\
\hline $\begin{array}{l}\text { 3. Memahami } \\
\text { pengetahuan } \\
\text { (faktual, konseptual, } \\
\text { dan } \\
\text { prosedural) } \\
\text { berdasarkan rasa } \\
\text { ingin tahunya tentang } \\
\text { ilmu } \\
\text { pengetahuan, } \\
\text { teknologi, seni, } \\
\text { budaya terkait }\end{array}$ & $\begin{array}{l}\text { 3. Memahami dan } \\
\text { menerapkan } \\
\text { pengetahuan (faktual, } \\
\text { konseptual, dan } \\
\text { prosedural) } \\
\text { berdasarkan rasa ingin } \\
\text { tahunya tentang ilmu } \\
\text { pengetahuan, } \\
\text { teknologi, seni, } \\
\text { budaya terkait }\end{array}$ & $\begin{array}{l}\text { Memahami dan } \\
\text { menerapkan } \\
\text { pengetahuan (faktual, } \\
\text { konseptual, dan } \\
\text { prosedural) } \\
\text { berdasarkan rasa ingin } \\
\text { tahunya tentang ilmu } \\
\text { pengetahuan, } \\
\text { teknologi, seni, } \\
\text { budaya terkait }\end{array}$ \\
\hline
\end{tabular}




\begin{tabular}{|c|c|c|}
\hline $\begin{array}{l}\text { fenomena dan } \\
\text { kejadian tampak mata. }\end{array}$ & $\begin{array}{l}\text { fenomena dan } \\
\text { kejadian tampak mata. }\end{array}$ & $\begin{array}{l}\text { fenomena dan } \\
\text { kejadian tampak mata. }\end{array}$ \\
\hline $\begin{array}{l}\text { 4. Mencoba, mengolah, } \\
\text { dan } \\
\text { menyaji dalam ranah } \\
\text { konkret } \\
\text { (menggunakan, } \\
\text { mengurai, } \\
\text { merangkai, } \\
\text { memodifikasi, dan } \\
\text { membuat) dan ranah } \\
\text { abstrak (menulis, } \\
\text { membaca, } \\
\text { menghitung, } \\
\text { menggambar, dan } \\
\text { mengarang) sesuai } \\
\text { dengan yang } \\
\text { dipelajari di } \\
\text { sekolah dan sumber } \\
\text { lain yang sama dalam } \\
\text { sudut } \\
\text { pandang/teori. }\end{array}$ & $\begin{array}{l}\text { 4. Mengolah, menyaji } \\
\text { dan } \\
\text { menalar dalam ranah } \\
\text { konkret } \\
\text { (menggunakan, } \\
\text { mengurai, } \\
\text { merangkai, } \\
\text { memodifikasi, dan } \\
\text { membuat) dan ranah } \\
\text { abstrak (menulis, } \\
\text { membaca, } \\
\text { menghitung, } \\
\text { menggambar, dan } \\
\text { mengarang) sesuai } \\
\text { dengan yang dipelajari } \\
\text { di } \\
\text { sekolah dan sumber } \\
\text { lain yang sama dalam } \\
\text { sudut } \\
\text { pandang/teori. }\end{array}$ & $\begin{array}{l}\text { 4. Mengolah, menyaji } \\
\text { dan } \\
\text { menalar dalam ranah } \\
\text { konkret } \\
\text { (menggunakan, } \\
\text { mengurai, } \\
\text { merangkai, } \\
\text { memodifikasi, } \\
\text { dan membuat) dan } \\
\text { ranah } \\
\text { abstrak (menulis, } \\
\text { membaca, } \\
\text { menghitung, } \\
\text { menggambar, } \\
\text { dan mengarang) } \\
\text { sesuai dengan yang } \\
\text { dipelajari di } \\
\text { sekolah dan sumber } \\
\text { lain yang sama dalam } \\
\text { sudut } \\
\text { pandang/teori. }\end{array}$ \\
\hline
\end{tabular}

Kompetensi Dasar dibutuhkan untuk mendukung pencapaian kompetensi lulusan melalui Kompetensi Inti. Selain itu, Kompetensi Dasar diorganisir ke dalam berbagai mata pelajaran yang pada giliranya berfungsi sebagai sumber kompetensi. Mata pelajaran yang dipergunakan sebagai sumber kompetensi tersebut harus mengacu pada ketentuan yang tercantum pada Undang-undang Sistem Pendidikan Nasional Nomor 20 Tahun 2003, khususnya ketentuan pada Pasal 37. Selain jenis mata pelajaran yang diperlukan untuk membentuk kompetensi, juga diperlukan beban belajar per minggu dan per semester atau per tahun. Beban belajar ini kemudian didistribusikan ke berbagai mata pelajaran sesuai dengan tuntutan kompetensi yang diharapkan dapat dihasilkan oleh tiap mata pelajaran.

Tabel 2.

Beban Belajar dan Struktur Kurikulum Madrasah Tsanawiyah (MTs)

\begin{tabular}{|c|c|c|c|c|}
\hline \multirow{3}{*}{\multicolumn{2}{|c|}{ MATA PELAJARAN }} & \multirow{2}{*}{\multicolumn{3}{|c|}{$\begin{array}{c}\text { ALOKASI WAKTU } \\
\text { BELAJAR } \\
\text { PER MINGGU }\end{array}$}} \\
\hline & & & & \\
\hline & & VII & VIII & IX \\
\hline \multicolumn{5}{|c|}{ Kelompok A } \\
\hline & Pendidikan Agama Islam & 2 & 2 & 2 \\
\hline & a. Al-Qur'an-Hadis & 2 & 2 & 2 \\
\hline
\end{tabular}




\begin{tabular}{clccc}
\hline & b. Akidah-Akhlak & 2 & 2 & 2 \\
& c. Fikih & 2 & 2 & 2 \\
& d. Sejarah Kebudayaan Islam & 2 & 2 & 2 \\
$\mathbf{2}$ & Pendidikan Pancasila dan Kewarganegaraan & 3 & 3 & 3 \\
$\mathbf{3}$ & Bahasa Indonesia & 6 & 6 & 6 \\
$\mathbf{4}$ & Bahasa Arab & 3 & 3 & 3 \\
$\mathbf{5}$ & Matematika & 5 & 5 & 5 \\
$\mathbf{6}$ & Ilmu Pengetahuan Alam & 5 & 5 & 5 \\
$\mathbf{7}$ & Ilmu Pengetahuan Sosial & 4 & 4 & 4 \\
$\mathbf{8}$ & Bahasa Inggris & 4 & 4 & 4 \\
$\mathbf{K e l o m p o k}$ B & & & \\
$\mathbf{1}$ & Seni Budaya & 3 & 3 & 3 \\
$\mathbf{2}$ & Pendidikan Jasmani, Olahraga, dan Kesehata & 3 & 3 & 3 \\
$\mathbf{3}$ & Prakarya & 2 & 2 & 2 \\
\hline
\end{tabular}

Beban belajar merupakan keseluruhan kegiatan yang harus diikuti peserta didik dalam satu minggu, satu semester, dan satu tahun pembelajaran. 1. Beban belajar di Madrasah Tsanawiyah dinyatakan dalam jam pembelajaran per minggu. Beban belajar satu minggu Kelas VII, VIII, dan IX adalah 46 jam pembelajaran. Durasi setiap satu jam pembelajaran adalah 40 menit. 2. Beban belajar di Kelas VII, VIII, dan IX dalam satu semester paling sedikit 18 minggu dan paling banyak 20 minggu. 3. Beban belajar di kelas IX pada semester ganjil paling sedikit 18 minggu dan paling banyak 20 minggu. 4. Beban belajar di kelas IX pada semester genap paling sedikit 14 minggu dan paling banyak 16 minggu. 5. Beban belajar dalam satu tahun pelajaran paling sedikit 36 minggu dan paling banyak 40 minggu.

Namun, mulai tahun pelajaran 2020/2021 KMA RI Nomor 165 Tahun 2014 ini sudah tidak berlaku dan tidak lagi menjadi acuan kurikulum di Madrasah, hal ini karena kementrian agama telah menerbitkan aturan baru yang akan dijadikan pedoman pelaksanaan kurikulum PAI di madrasah, yaitu dengan terbitnya dua keputusan menteri agama. Pertama, KMA RI Nomor 183 Tahun 2019 tentang Kurikulum Pendidikan Agama Islam dan Bahasa Arab pada Madrasah. Kedua, KMA RI Nomor 184 Tahun 2019 tentang Pedoman Implementasi Kurikulum pada Madrasah. Jadi, mulai tahun pelajaran 2020/2021 kurikulum di Madrasah akan mengacu pada kedua aturan ini. Akan tetapi, walaupun sudah berganti regulasi, jumlah jam mata pelajaran PAI tidak mengalami perubahan dari sebelumnya yaitu tetap berjumlah delapan jam pelajaran yang terdiri dari 2 jam pelajaran Al-Quran Hadis, 2 jam pelajaran Akidah Akhlak, dua jam pelajaran Fikih, dan dua jam pelajaran SKI.

2. Kurikulum yang digunakan di MTs Plus Karangwangi

MTs Plus Karangwangi merupakan lembaga pendidikan Islam yang didirikan oleh Yayasan Binong Center pada tahun 2012. Lembaga pendidikan ini 
mulai beroperasi pada tahun pelajaran 2012/2013. MTs Plus Karangwangi berada dibawah naungan Kementerian Agama Republik Indonesia, sehingga kurikulum yang digunakannya pun mengacu kepada Keputusan Menteri Agama Republik Indonesia Nomor: 165 Tahun 2014 tentang Kurikulum 2013 Mata Pelajaran Pendidikan Agama Islam dan Bahasa Arab pada Madrasah.

3. Perbedaan Jumlah Jam Pelajaran PAI dalam Kurikulum 2013 Kementrian Agama dan Kurikulum 2013 Kementerian Pendidikan dan Kebudayaan

Berdasarkan Keputusan Menteri Agama Republik Indonesia Nomor: 165 Tahun 2014 tentang Kurikulum 2013 Mata Pelajaran Pendidikan Agama Islam dan Bahasa Arab pada Madrasah, bahwa jumlah jam pelajaran PAI untuk tingkat Madrasah Tsanawiyah (MTs) dalam kurikulum 2013 sebanyak 8 (delapan) jam pelajaran, dengan rincian pelajaran PAI sebagai berikut:

a) Al-Qur' an Hadis sebanyak 2 (dua) jam pelajaran;

b) Akidah Akhlak sebanyak 2 (dua) jam pelajaran;

c) Fikih sebanyak 2 (dua) jam pelajaran;

d) Sejarah Kebudayaan Islam sebanyak 2 (dua) jam pelajaran;

Sedangkan jumlah jam pelajaran PAI untuk tingkat SMP dalam kurikulum 2013 yang dikeluarkan Kementerian Pendidikan dan Kebudayaan sebanyak 3 (tiga) jam pelajaran. Dengan demikian ada perbedaan jumlah jam pelajaran PAI dari kedua kurikulum 2013 tersebut yakni jumlah jam pelajaran PAI pada kurikulum yang dikeluarkan Kementerian Agama lebih banyak dibandingkan dengan jumlah jam pelajaran PAI pada kurikulum yang dikeluarkan Kementrian Pendidikan dan Kebudayaan dengan selisih 5 (lima) jam pelajaran.

\section{Tabel 3.}

Perbandingan Jumlah Jam Mata Pelajaran PAI dalam Kurikulum 2013 yang dikeluarkan Kementerian Agama dan Kurikulum 2013 yang dikeluarkan Kementrian Pendidikan dan Kebudayaan

\begin{tabular}{|c|c|c|c|}
\hline \multicolumn{2}{|c|}{ KURIKULUM 2013 KEMENAG } & \multicolumn{2}{|c|}{ KURIKULUM 2013 KEMENDIKBUD } \\
\hline Mata Pelajaran & Jumlah Jam & Mata Pelajaran & Jumlah Jam \\
\hline $\begin{array}{l}\text { 1. Al-Qur'an } \\
\text { Hadis }\end{array}$ & $2 \mathrm{JTM}$ & 1. PAI & $3 \mathrm{JTM}$ \\
\hline 2. Akidah Akhlak & $2 \mathrm{JTM}$ & & \\
\hline 3. Fikih & $2 \mathrm{JTM}$ & & \\
\hline 4. SKI & $2 \mathrm{JTM}$ & & \\
\hline Jumlah Total JTM & $8 \mathrm{JTM}$ & Jumlah Total JTM & 3 JTM \\
\hline
\end{tabular}

4. Jumlah Jam Pelajaran dan Materi PAI di MTs Plus Karangwangi

Jumlah jam pelajaran dan materi PAI yang diterapkan di MTs Plus Karangwangi mengacu pada kurikulum resmi yang dikeluarkan Kementerian Agama Republik Indonesia yaitu dengan jumlah jam PAI sebanyak 8 (delapan) jam pelajaran dengan rincian: Al-Qur'an Hadis sebanyak 2 jam pelajaran, Akidah Akhlak sebanyak 2 jam pelajaran, Fikih sebanyak 2 jam pelajaran dan SKI 
sebanyak 2 jam pelajaran. Begitu juga dengan materi pembelajaran PAI nya sesuai dengan kurikulum resmi Kementerian Agama. Selain itu, madrasah ini menambah jam dan materi PAI nya dalam pembelajaran di kelas. Materi tambahan pelajaran PAI tersebut menggunakan kitab kuning, yaitu kitab safinah dan kitab fathul qorib. Untuk lebih jelasnya dapat dilihat dalam tabel berikut.

Tabel 4.

Beban Belajar dan Struktur Kurikulum PAI

Di MTs Plus Karangwangi Subang

\begin{tabular}{|c|c|c|c|}
\hline \multirow[t]{2}{*}{ MATA PELAJARAN PAI } & \multicolumn{3}{|c|}{$\begin{array}{l}\text { ALOKASI WAKTU } \\
\text { BELAJAR }\end{array}$} \\
\hline & VII & VIII & IX \\
\hline \multicolumn{4}{|l|}{$\begin{array}{l}\text { 1. Mata Pelajaran Pokok sesuai Kurikulum } \\
\text { Kemenag }\end{array}$} \\
\hline a. Al-Qur'an Hadis & 2 & 2 & 2 \\
\hline b. Akidah Akhlak & 2 & 2 & 2 \\
\hline c. Fikih & 2 & 2 & 2 \\
\hline d. SKI & 2 & 2 & 2 \\
\hline Jumlah & 8 & 8 & 8 \\
\hline \multicolumn{4}{|l|}{ 2. Mata Pelajaran PAI Tambahan } \\
\hline a. Kitab Kuning: Safinah & 2 & 2 & - \\
\hline b. Kitab Kuning: Fathul Qorib & - & - & 2 \\
\hline c. Baca Tulis Qur'an & 2 & 2 & 2 \\
\hline Jumlah & 4 & 4 & 4 \\
\hline Jumlah Total & 12 & 12 & 12 \\
\hline
\end{tabular}

5. Proses Pembelajaran dan Buku Sumber PAI

\section{Proses Pembelajaran}

Berdasarkan hasil penelitian, bahwa proses pembelajaran PAI (Al-Qur'an Hadis, Akidah Akhlak, Fikih dan SKI) di MTs Plus Karangwangi mengacu pada buku guru yang diterbitkan oleh Kementerian Agama Republik Indonesia. Sehingga metode dan strategi pembelajarannya pun berpariasi sesuai dengan petunjuk yang ada dalam buku guru tersebut. Sedangkan mengenai materi pelajaran kitab kuning proses pembelajaran dilakukan dengan sistem bandongan. Dalam sistem ini semua murid mendengarkan seorang guru yang membaca, menerjemahkan, menerangkan dan seringkali mengulas buku-buku Islam dalam Bahasa Arab. Setiap murid memperhatikan bukunya sendiri dan membuat catatan tentang kata-kata atau buah pikiran yang sulit, berupa syakl atau makna mufrodhat atau penjelasan (keterangan tambahan). Sebelum mulai pembelajaran guru terlebih dahulu menyuruh salah satu siswa untuk membacakan kitab pelajaran yang lalu.

\section{Buku Sumber}

Buku sumber mata pelajaran PAI (Al-Qur'an Hadis, Akidah Akhlak, Fikih dan SKI) di MTs Puls Karangwangi Subang menggunakan buku yang dikeluarkan oleh Kementerian Agama Republik Indonesia sedangkan mata 
pelajaran PAI tambahan menggunakan kitab kuning, yaitu kitab Safinah dan Kitab Fathul Qorib. Untuk lebih jelasnya perhatikan tabel 05 berikut.

Tabel 5.

Buku Sumber Mata Pelajaran PAI

Di MTs Plus Karangwangi Subang

\begin{tabular}{|c|c|}
\hline Mata Pelajaran & Nama Buku \\
\hline \multicolumn{2}{|c|}{ A. Mata Pelajaran Pokok sesuai Kurikulum Kemenag } \\
\hline $\begin{array}{l}\text { 1. Al-Qur'an } \\
\text { Hadis }\end{array}$ & Buku Siswa dan Buku Guru Al-Qur'an Hadis \\
\hline 2. Akidah Akhlak & Buku Siswa dan Buku Guru Akidah Akhlak \\
\hline 3. Fikih & Buku Siswa dan Buku Guru Fikih \\
\hline 4. SKI & Buku Siswa dan Buku Guru SKI \\
\hline \multicolumn{2}{|c|}{ B. Mata Pelajaran PAI Tambahan } \\
\hline 5. Kitab Kuning & Kitab Safinah \\
\hline 6. Kitab Kuning & Kitab Fathul Qorib \\
\hline
\end{tabular}

\section{SIMPULAN}

Berdasarkan hasil penelitian dapat dikemukakan kesimpulan bahwa menjadi penting menambah jumlah jam dan materi pelajaran PAI di sekolah/madrasah, karena pelajaran agama yang begitu banyak tidak mungkin bisa dipelajari oleh siswa hanya dengan 3 sampai 8 jam pelajaran saja dalam satu minggunya. Hal ini mengingat bahwa sangat pentingnya fungsi pendidikan agama sebagai usaha membina kehidupan beragama, dan sebagai pembangunan manusia Indonesia seutuhnya dan masyarakat Indonesia seluruhnya.

\section{REFERENSI}

At-Taubany, T. I. B., \& Susena, H. (2017). Desain Pengembangan Kurikulum 2013 Di Madrasah (1st ed.). Depok: Kencana.

Dahwadin, \& Nugraha, F. S. (2019). Motivasi dan Pembelajaran Pendidikan Agama Islam (1st ed.). Wonosobo, Jawa Tengah: CV. Mangku Bumi Media.

H. Tahang, J. (2010). Urgensi Pendidikan Agama dalam Keluarga Terhadap Pembentukan Kepribadian Anak. HUNAFA: Jurnal Studia Islamika, 7(2), 163. https://doi.org/10.24239/jsi.v7i2.99.163-178

Kosim, A., \& Faturrohman, N. (2018). Pendidikan Agama Islam sebagai Core Ethical Values untuk Perguruan Tinggi Umum (1st ed.; Engkus Kuswandi, ed.). Bandung: PT Remaja Rosdakarya.

Lismina. (2017). Pengembangan Kurikulum (1st ed.; Imam Mohtar, ed.). Ponorogo: Uwais Inspirasi Indonesia.

Moleong, L. J. (2003). Metode Penelitian Kualitatif. Bandung: Remaja Rosda Karya. Moleong, L. J. (2008). Metodologi Penelitian Kualitatif. Bandung: Remaja Rosdakarya.

Mukhtaruddin. (2011). Pengaruh Pendidikan Agama Terhadap Perilaku 
Keagamaan Peserta Didik. Analisa: Jurnal Ilmu Sosial Dan Agama, 18(1), 133. https://doi.org/10.18784/analisa.v18i1.129

Munir. (2018). Pengembangan Materi Pendidikan Agama Islam (PAI) Berbasis Kitab Kuning dan Signifikansinya dengan Karakter Siswa SMA Ahmad Yani 2 Baureno Bojonegoro. Edu-Religia: Jurnal Keagamaan Dan Pembelajarannya, 1(Vol 1 No 2 (2018): Septemeber). Retrieved from http://ejurnal.unisda.ac.id/index.php/edureg/article/view/1616

Nata, A. (2012). Manajemen Pendidikan: Mengatasi Kelemahan Pendidikan Islam di Indonesia (4th ed.). Jakarta: Kencana Prenada Media Group.

Sarinah. (2015). Pengantar Kurikulum (1st ed.). Yogyakarta: Deepublish.

Shobirin, M. (2016). Konsep dan Implementasi Kurikulum 2013 di Sekolah Dasar (1st ed.). Yogyakarta: Deepublish.

Sugiyono. (2009). Meetode Penelitian Pendidikan, Pendekatan Kuantitatif, Kualitatif, dan $R$ Eamp; D. Bandung: Alfabeta.

Syaifullah. (2017). Pendidikan Karakter Melalui Pembelajaran Kitab Kuning (Risalatul Muawwanah) di SMA MMa'arif Sukorejo. Jurnal Mafhum: Ilmu AlQur'an Dan Tafsir, 2(2), 321-340. Retrieved from https://jurnal.yudharta.ac.id/v2/index.php/mafhum/article/view/948

Syarif, M. (2017). Penguatan Pendidikan Agama Islam (PAI) sebagai Kurikulum Inti di Sekolah. PIGUR: Jurnal Pendidikan Guru, 2. Retrieved from https://ejournal.unri.ac.id/index.php/pigur/article/view/5451

Undang-Undang Republik Indonesia Nomor 20 Tahun 2003 Tentang Sistem Pendidikan Nasional. 